\title{
APLIKASI MATLAB PADA INTEGRAL LIPAT DUA
}

\author{
Ade Putra Tampubolon ${ }^{1}$, Kathrin Nissiputri Lase ${ }^{2}$, Klara Miranda Situngkir ${ }^{3}$, Shinta Sianturi ${ }^{4}$ \\ Jurusan Matematika, Fakultas Matematika dan Ilmu Pengetahuan Alam \\ Universitas Negeri Medan \\ Jl. Willem Iskandar Ps. V Medan Estate, Medan 20221 \\ 1ade.putratampubolon18@gmail.com \\ ${ }^{2}$ kathrinnissi@gmail.com \\ ${ }^{3}$ klaramiranda53@gmail.com \\ ${ }^{4}$ shintakevinevelinsianturi@gmail.com
}

\begin{abstract}
Mathematics is one of the sciences that has an important function in various fields of science. In the Mathematics study program, calculus is a subject that often encounters integral problems, especially double integrals. The purpose of this study was to find out the difficulties of students in solving double integral problems and to compare the working process using Matlab. The research method used is literature study. From the research results, it is known that using Matlab can be faster, easier and more efficient in solving math problems compared to manual completion. Because the level of calculation errors in manual completion is easier to occur, so it is not uncommon to have to rework from scratch to get really accurate results. Therefore, Matlab is recommended as one of the good software to use in understanding material, especially mathematics.
\end{abstract}

Keywords: Double Integral, MATLAB

\begin{abstract}
Abstrak : Matematika adalah salah satu ilmu yang mempunyai fungsi penting di berbagai bidang ilmu pengetahuan. Pada program studi Matematika, kalkulus merupakan mata kuliah yang sering dijumpai permasalahan integral, khususnya integral lipat dua. Tujuan penelitian ini adalah untuk mengetahui kesulitan mahasiswa dalam menyelesaikan soal integral lipat dua dan membandingkan proses pengerjaan dengan menggunakan Matlab. Metode penelitian yang digunakan adalah studi kepustakaan. Dari hasil penelitian diketahui bahwa dengan menggunakan Matlab dapat lebih cepat, mudah dan efisien dalam menyelesaikan soal matematika dibandingkan dengan penyelesaian secara manual. Karena tingkat kesalahan perhitungan dalam penyelesaian secara manual lebih mudah terjadi, sehingga tak jarang harus mengerjakan ulang dari awal hingga mendapatkan hasil yang benar-benar akurat. Oleh karena itu, Matlab disarankan sebagai salah satu software yang baik untuk digunakan dalam memahami materi, khususnya matematika.
\end{abstract}

Kata kunci: Integral lipat dua, MATLAB 


\section{PENDAHULUAN}

Matematika adalah salah satu ilmu yang mempunyai fungsi penting di berbagai bidang ilmu pengetahuan. Dalam mempelajari matematika, mahasiswa harus didorong pada konsep penalaran, pemahaman dan pengaplikasian soal dalam menyelesaikan suatu masalah agar mahasiswa dapat berpikir kritis, cermat, terstruktur, logis, efektif, dan sistematis dalam memecahkan masalah yang dihadapi. Pada program studi Matematika, kalkulus merupakan mata kuliah yang harus ditempuh oleh seluruh mahasiswa matematika. Mata kuliah kalkulus lanjut mempelajari tentang integral lipat dua atas daerah persegi panjang, integral lipat dua atas daerah umum $\mathrm{R}$, integral lipat dua dalam kordinat polar/kutub, integral lipat tiga dan aplikasi integral lipat tiga.

Integral mempunyai fungsi yang penting dalam berbagai bidang industri dan sains. Integral memiliki beberapa fungsi yang dipergunakan dalam memecahkan persoalan dalam berbagai bidang seperti panjang kurva, perkiraan populasi, usaha, volume, luas selimut, dan sebagainya. Dalam menyelesaikan soal integral lipat dua, mahasiswa masih banyak yang mengalami kesulitan. Kesulitan yang dialami untuk memecahkan masalah terkait integral lipat dapat memungkinkan melemahnya minat dan motivasi mahasiswa dalam mempelajari dan memecahkan masalah tersebut.

Menurut Wahyuni (2017), pembelajaran matematika merupakan aktivitas siswa yang memahami hubungan, norma serta simbol. Dalam hal ini, pembelajaran matematika terutama materi integral memiliki beberapa simbol yang digunakan. Simbol-simbol dalam pembelajaran integral masih membuat mahasiswa kebingungan dikarenakan tidak terlalu menghafal nama dan bentuk simbol tersebut.

Dalam dunia pendidikan di zaman ini, perkembangan dan kehadiran teknologi komputer telah banyak memberikan kemudahan berbagai pihak untuk menggunakannya sebagai sarana penunjang pendidikan. Hal tersebut dikarenakan dengan menggunakan komputer dapat mempertinggi efisiensi suatu pekerjaan karena adanya kelebihan/manfaat dari komputer. Kelebihan tersebut diantaranya adalah dapat mengerjakan pekerjaan dengan cepat dan tepat, dapat menyimpan data dan dapat memproses data/informasi dalam cakupan besar. Program-program komputer ini sangat membantu, khususnya dalam proses pembelajaran.

Terdapat ratusan bahkan ribuan program aplikasi atau perangkat lunak yang dapat dimanfaatkan untuk pembelajaran matematika. Salah satu perangkat lunak yang dapat digunakan dalam pembelajaran Kalkulus, khususnya mengenai integral lipat dua, yaitu Matrix Laboratory (MATLAB). Program ini dapat dimanfaatkan untuk meningkatkan kecepatan dan keakuratan dalam berbagai perhitungan integral lipat dua sehingga waktu yang diperlukan untuk mengerjakan lebih efisien dan hasil yang diperoleh lebih akurat dibandingkan dengan perhitungan yang dilakukan secara manual, juga dapat memvisualisasikan grafik dalam bentuk 2 dimensi maupun 3 dimensi yang tentu saja sulit jika digambar secara manual, sehingga diharapkan dengan menggunakan Matlab dapat meningkatkan pemahaman terhadap materi kalkulus yang dipelajari.

Tujuan penelitian ini adalah untuk mengetahui bagaimana prosedur menggunakan Matlab dalam menyelesaikan soal integral lipat dua dan membandingkan hasil yang diperoleh dengan pengerjaan secara manual. Dengan demikian, dalam penelitian ini penulis membatasi ruang lingkup permasalahan penelitian antara lain: penyelesaian integral lipat dibatasi dua variabel bebas yaitu $x$ dan $y, f(x, y)$ merupakan fungsi aljabar, batas integral lipat bernilai konstan dan program yang digunakan adalah Matlab. 


\section{METODE PENELITIAN}

Metode penelitian yang digunakan oleh penulis adalah Studi literatur (Kajian pustaka). Studi pustaka merupakan penelaahan sumber pustaka yang relevan digunakan untuk mengumpulkan data maupun informasi yang terdapat di ruang perpustakaan, seperti bukubuku, data dari internet, jurnal dan lain-lain yang menyangkut penelitian.

\section{KAJIAN PUSTAKA}

a. Integal Lipat Dua

Mengingat kalkulus bahwa $\int_{a}^{b} y d x=\int_{a}^{b} f(x) d x$ menyatakan suatu luasan di bawah kurva. Ingat juga definisi integral sebagai limit dari suatu jumlah. Kita perkirakan suatu luasan dengan jumlah empat persegi panjang yang mempunyai lebar $\Delta x$. Secara geometri menunjukkan bahwa bila kita menambah jumlah empat persegi panjang dan memisalkan lebar $\Delta x \rightarrow 0$, penjumlahan luasan empat persegi panjang akan condong ke luasan di bawah kurva.

Didefinisikan $\int_{a}^{b} f(x) d x$ sebagai limit dari jumlah luas empat persegi panjang maka kita evaluasi integral sebagai anti derivative dan menggunakan $\int_{a}^{b} f(x) d x$ untuk menghitung luasan di bawah kurva.

Akan kita kerjakan sesuatu dengan cara sama untuk mendapatkan volume silinder di bawah permukaan $z=f(x, y)$. Kita potong bidang $(x, y)$ dalam empat persegi panjang kecil-kecil dengan luas $\Delta A=(\Delta x)(\Delta y)$, di atas $(\Delta x)(\Delta y)$ adalah kotak kecil tinggi mencapai permukaan. Volume dapat diperkirakan dengan menjumlahkan empat persegi panjang.

Di definisikan integral lipat dua dari $f(x, y)$ yang meliputi luasan $A$ dalam bidang $(x, y)$ sebagai limit dari penjumlahan ini dan dituliskan sebagai:

$$
\iint_{A} f(x, y) d x d y
$$

A disebut daerah integrasi, $f(x, y)$ disebut integran, $x$ dan $y$ dinamakan variabel integrasi.

Suatu fungsi dua variabel $\mathrm{f}(\mathrm{x}, \mathrm{y})$ yang kontinu pada persegi panjang $S=\{(\mathrm{x}, \mathrm{y}) ; \mathrm{a} \leq \mathrm{x} \leq \mathrm{b}$; $\mathrm{c} \leq \mathrm{y} \leq \mathrm{d}\}$ dapat diintegrasikan pada bidang tersebut. Integral fungsi dua variabel $f(x, y)$ terhadap suatu luasan $\mathrm{A}(\mathrm{R})$ dinamakan integral lipat. Konsep integral lipat dibangun berdasarkan persegi panjang $S$ yang dipartisi penjadi persegi panjang yang kecil-kecil dan ditentukan luasnya. Penjumlahan bentuk perkalian $f(x, y) \Delta \mathrm{A}$ untuk semua partisi merupakan aproksimasi dari integral lipat dua dalam koordinat cartesius. Apabila partisi persegi panjang sangat kecil sehingga mendekati 0 maka integral lipat dua akan sangat dekat dengan penjumlahan bentuk $f(x, y) \Delta \mathrm{A}$.

Penerapan integral di bidang sains dan teknologi sering muncul dalam bentuk integral ganda dua (lipat dua) dan integral ganda tiga (lipat tiga). Pengertian integral lipat dua dapat ditulis dalam bentuk :

$$
\int_{y_{1}}^{y_{2}} \int_{x_{1}}^{x_{2}} f(x, y) d x d y
$$

Maksud dari bentuk diatas yaitu pengintegralan pertama dilakukan terhadap $x$ dengan memandang $f(x, y)$ sebagai fungsi dari $\mathrm{x}$ dan y dianggap tetap atau konstan, sedang 
batas integral yaitu $x_{1}$ ke $x_{2}$, kemudian hasil integral pertama diintegralkan terhadap y dengan batas integral yaitu $y_{1}$ ke $y_{2}$. Integral lipat dua dalam koordinat cartesius dapat dihitung dengan integral berulang dengan urutan $\mathrm{dx}$ dy atau sebaliknya dy $\mathrm{dx}$ asalkan batasnya sesuai. Konsep integral berulang dapat dimaknai sebagai proses integrasi suatu fungsi dua variabel $f(x, y)$ terhadap $x$ dilanjutkan terhadap $y$, atau sebaliknya.

b. Pemrograman Matlab

Matlab (Matrix Laboratory) adalah suatu program untuk analisis dan komputasi numerik dan merupakan suatu bahasa pemrograman matematika lanjutan yang dibentuk dengan dasar pemikiran menggunakan sifat dan bentuk matriks. Matlab telah berkembang menjadi sebuah environment pemrograman yang canggih yang berisi fungsi-fungsi built-in untuk melakukan tugas pengolahan sinyal, aljabar linier, dan kalkulasi matematis lainnya. Matlab juga berisi toolbox yang berisi fungsi-fungsi tambahan untuk aplikasi khusus.

Matlab merupakan merk software yang dikembangkan oleh Mathworks.Inc. dan merupakan software yang paling efisien untuk perhitungan numerik berbasis matriks. Sehingga Matlab banyak digunakan pada : (1) Matematika dan Komputasi, (2) Pengembangan dan Algoritma, (3) Pemrograman modeling, simulasi, dan pembuatan prototype, (4) Analisa Data, eksplorasi dan visualisasi, (5) Analisis numerik dan statistik, dan (6) Pengembangan aplikasi teknik.

Ada beberapa macam window yang tersedia dalam Matlab, yang dapat dijelaskan sebagai berikut:

- Command window/editor

Matlab Command window/editor merupakan window yang dibuka pertama kali setiap kali Matlab dijalankan pada window di atas dapat dilakukan akses- akses ke command Matlab dengan cara mengetikkan barisan-barisan ekpresi Matlab, seperti mengakses help window dan lain-lainnya. Command Window adalah tempat untuk menjalankan fungsi, mendeklarasikan variabel, menjalankan proses-proses, serta melihat isi variabel.

- Current Directory

Window ini menampilkan isi dari direktori kerja saat menggunakan Matlab. Kita dapat mengganti direktori ini sesuai dengan tempat direktori kerja yang diinginkan. Default dari alamat direktori berada dalam folder works tempat program files Matlab berada.

\section{- Command History}

Window ini berfungsi untuk menyimpan perintah-perintah apa saja yang sebelumnya dilakukan oleh pengguna terhadap Matlab.

- Workspace

Workspace berfungsi untuk menampilkan seluruh variabel-variabel yang sedang aktif pada saat pemakaian matlab. Apabila variabel berupa data matriks berukuran besar maka user dapat melihat isi dari seluruh data dengan melakukan double klik pada variabel tersebut. Matlab secara otomatis akan menampilkan window "array editor" yang berisikan data pada setiap variabel yang dipilih user.

\section{HASIL DAN PEMBAHASAN}

Pemahaman ini dilakukan dengan menelusuri beberapa artikel jurnal terkait dengan pemahaman mahasiswa tentang integral lipat dua dan pengaplikasiannya di Matlab. 
Bentuk kesalahan yang dilakukan mahasiswa pada materi integral lipat dua adalah salah dalam menentukan hubungan batas atas dan bawah dengan sumbu yang akan diintegralkan. Untuk dapat menentukan batas integral, mahasiswa harus dapat menggambarkan terlebih dahulu bentuk daerah sebagai batas integralnya. Ketika batas ditentukan dengan cara memandang $\mathrm{x}$-sederhana, maka batas pada sumbu y dipertahankan konstan (Muchlis, 2017).

Dalam penelitian ini, diberikan tiga contoh soal integral lipat dua sebagai berikut:

1) $\int_{-1}^{1} \int_{1}^{2}\left(x^{2}+y^{2}\right) d x d y$

2) $\int_{1}^{2} \int_{0}^{3}\left(x y+y^{2}\right) d x d y$

3) $\int_{0}^{2} \int_{1}^{3}\left(x^{2} y\right) d y d x$

Dari beberapa jurnal yang sudah dikaji, secara umum kesalahan mahasiswa dapat dilihat sebagai berikut.

1. $\int_{-1}^{1} \int_{1}^{2}\left(x^{2}+y^{2}\right) d y d x$

2. $\int_{1}^{2} \int_{0}^{3}\left(x y+y^{2}\right) d y d x$

3. $\int_{0}^{2} \int_{1}^{3}\left(x^{2} y\right) d x d y$

Bentuk diatas adalah penulisan yang salah dalam menentukan hubungan batas integral dalam sumbu integral. Faktor penyebab kesalahannya adalah tidak memahami maksud dalam mengambil batas dengan memandang bentuk x-sederhana ataupun y-sederhana. Masih banyak mahasiswa yang bingung dalam pengambilan batas integral lipat dengan memandang $\mathrm{x}$-sederhana ataupun y-sederhana. Hal tersebut menunjukkan bahwa mahasiswa belum dapat menghubungkan antara batas atas dan batas bawah dengan sumbu yang akan diintegralkan.

Adapun kesalahan lain yang ditemukan yaitu salah dalam mengintegralkan fungsi dengan teknik substitusi. Kesalahan ini disebabkan mahasiswa belum mampu mengidentifikasi bentuk fungsi untuk menentukan cara penyelesaian. Hal tersebut dapat terjadi dikarenakan kurangnya pemahaman mengenai cara penggunaan teknik substitusi dan bentuk-bentuk fungsi yang mengakibatkan kesulitan dalam menentukan cara penyelesaian integral lipat dua.

Menurut Nurhikmah dan Febrian (2016), jenis kesalahan yang dilakukan mahasiswa merupakan kesalahan yang diawali dari ketidaktahuan dalam rumus dasar integral dan kurang memahami konsep dasar dari materi integral. Pada kesalahan konsep, mahasiswa masih salah dalam menerapkan sifat integral. Masih ada mahasiswa yang belum memahami operasi dasar integral sehingga mengakibatkan kesalahan dalam menghitung (Wahyuni, Kurniawan, S.B, \& Cahyono, 2019).

Berikut dijelaskan penyelesaian soal-soal integral lipat dua secara manual dan disertai penyelesaian menggunakan Matlab.

1) $\int_{-1}^{1} \int_{1}^{2}\left(x^{2}+y^{2}\right) d x d y$

$$
=\int_{-1}^{1}\left[\frac{1}{3} x^{3}+x y^{2}\right]_{x=1}^{x}=2 d y
$$




$$
\begin{aligned}
& =\int_{-1}^{1}\left[\frac{8}{3}+2 y^{2}\right]-\left[\frac{1}{3}+y^{2}\right] d y \\
& =\int_{-1}^{1}\left[\frac{7}{3}+y^{2}\right] d y \\
& =\left[\frac{7}{3} y+\frac{1}{3} y^{3}\right]_{-1}^{1} \\
& =\left[\frac{7}{3}+\frac{1}{3}\right]-\left[-\frac{7}{3}-\frac{1}{3}\right] \\
& =\frac{16}{3} \approx 5,333
\end{aligned}
$$

Penyelesaian dengan Matlab:

Untuk penyelesaian soal integral lipat dua dapat menggunakan cara langsung di matlab dengan prosedur:

$>>$ dblquad ('function', xmin, xmax, ymin, ymax)

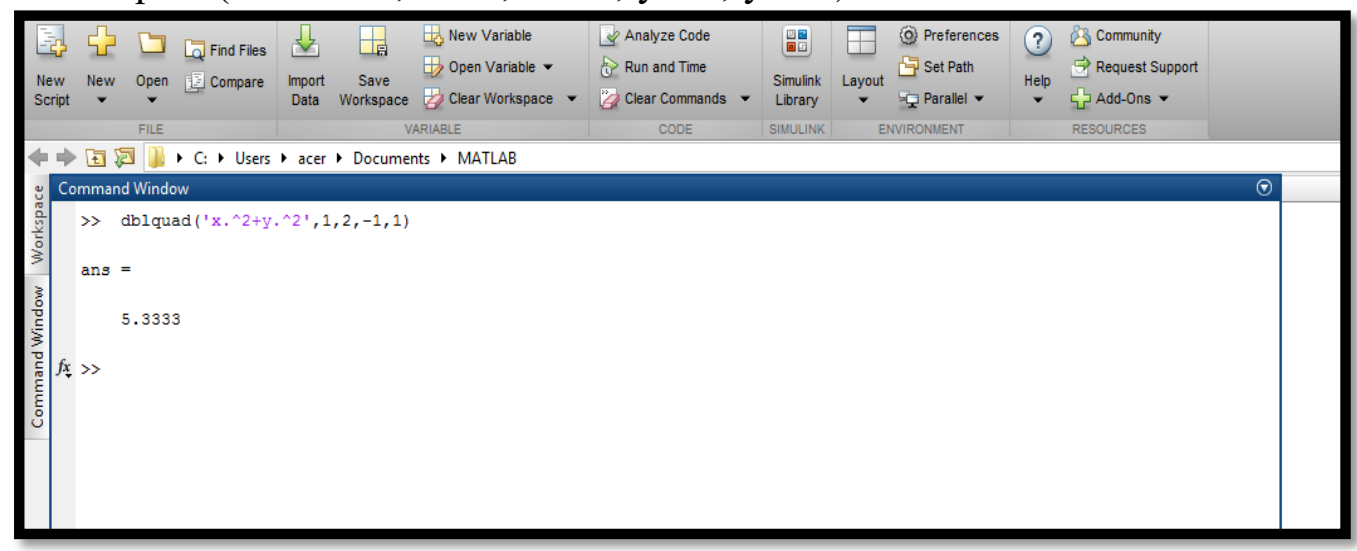

Diperoleh hasil yang sama dengan penyelesaian secara manual, yaitu 5,3333.

2). $\int_{1}^{2} \int_{0}^{3}\left(x y+y^{2}\right) d x d y$

Penyelesaian secara manual:

$$
\begin{aligned}
& =\int_{1}^{2}\left[\frac{1}{2} x^{2} y+x y^{2}\right]_{x=0}^{x=3} d y \\
& =\int_{1}^{2}\left[\frac{9}{2} y+3 y^{2}\right] d y \\
& =\left[\frac{9}{4} y^{2}+y^{3}\right]_{1}^{2} \\
& =\left[\frac{36}{4}+8\right]-\left[\frac{9}{4}+1\right] \\
& =\frac{55}{4} \approx 13,75
\end{aligned}
$$

Penyelesaian dengan Matlab: 
$>>$ dblquad ('function', xmin, xmax, ymin, ymax)

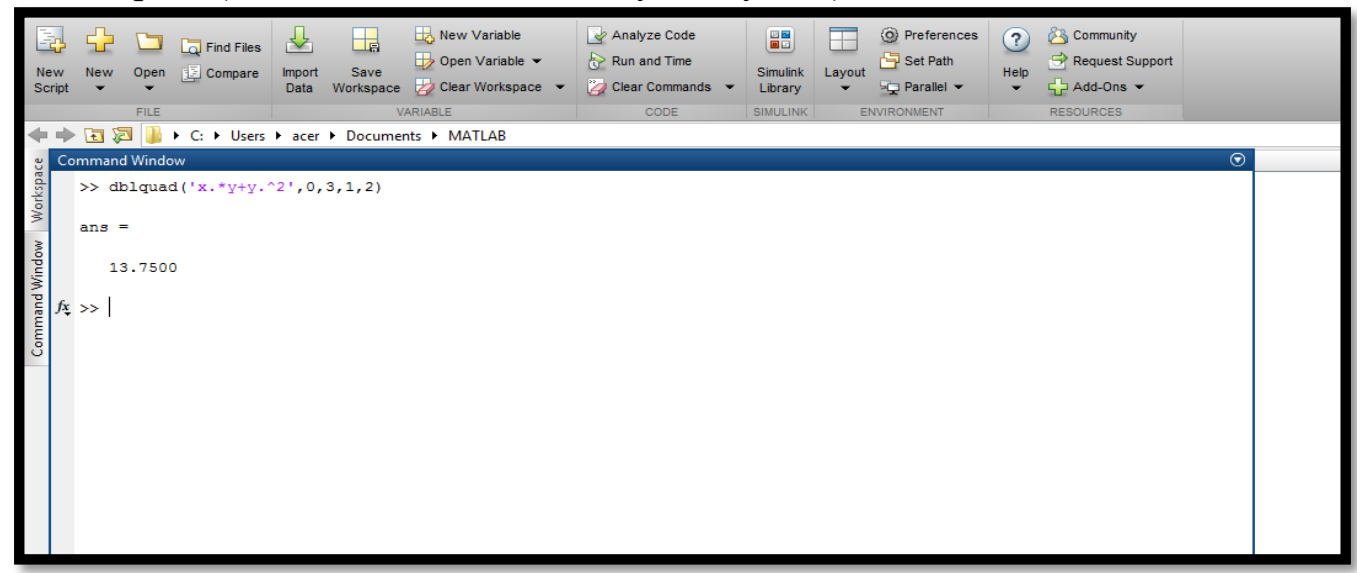

Diperoleh hasil yang sama dengan penyelesaian secara manual, yaitu: 13,75.

3). $\int_{0}^{2} \int_{1}^{3}\left(x^{2} y\right) d y d x$

Penyelesaian secara manual:

$$
\begin{aligned}
& =\int_{0}^{2}\left[\frac{1}{2} x^{2} y^{2}\right]^{y=3} \begin{array}{l}
y=1 \\
y
\end{array} \\
& =\int_{0}^{2}\left[\frac{1}{2} x^{2}(3)^{2}\right]-\left[\frac{1}{2} x^{2}(1)^{2}\right] d x \\
& =\int_{0}^{2}\left(\frac{9}{2} x^{2}-\frac{1}{2} x^{2}\right) d x \\
& =\int_{0}^{2} 4 x^{2} \\
& =\left[\frac{4}{3} x^{3}\right]_{0}^{2} \\
& =\left[\frac{4}{3}(2)^{3}\right]-0 \\
& =\frac{32}{3} \approx 10,67
\end{aligned}
$$

Penyelesaian dengan Matlab:

> dblquad ('function', xmin, xmax, ymin, ymax) 


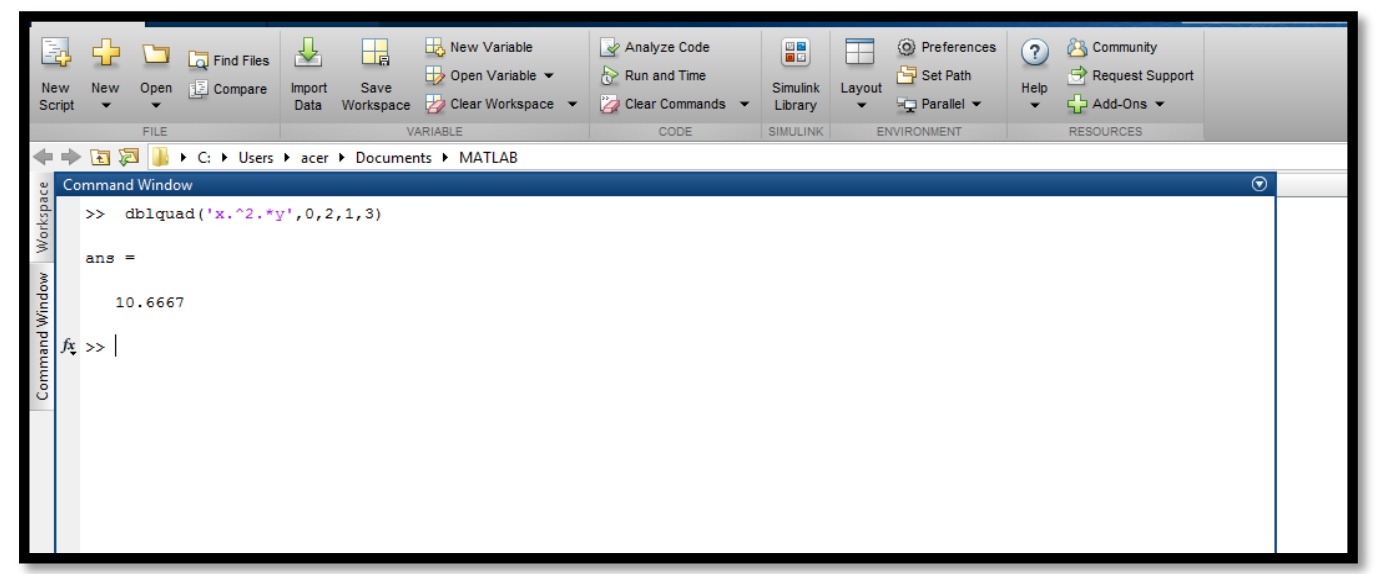

Diperoleh hasil yang sama dengan penyelesaian secara manual, yaitu: 10, 6667.

Dari pembahasan mengenai kesulitan mahasiswa dan penyelesaian ketiga contoh soal diatas, dapat diketahui bahwa penyelesaian soal secara manual membutuhkan waktu yang lebih lama dibandingkan dengan penyelesaian menggunakan Matlab. Dalam penyelesaian secara manual dibutuhkan ketelitian yang lebih mendalam dikarenakan tingkat kesalahan dalam perhitungan lebih mudah terjadi, sehingga tak jarang harus mengerjakan ulang dari awal hingga mendapatkan hasil yang benar-benar akurat.

Dengan menggunakan Matlab, penyelesaian soal matematika, khususnya integral lipat dua, dapat dikerjakan dengan cepat dan efisien serta mendapatkan hasil yang akurat, asalkan kita benar-benar memahami dan mengetahui prosedur atau algoritma dalam penyelesaian soal tersebut. Tetapi, alangkah lebih baik jika kita terlebih dahulu memahami konsep penyelesaian soal secara manual, agar tidak hanya sekedar hasil yang diketahui tetapi juga memahami bagaimana hasil tersebut diperoleh.

\section{KESIMPULAN DAN SARAN}

Dalam menyelesaikan soal integral lipat dua, masih ada beberapa kesalahan yang dilakukan mahasiswa, seperti salah dalam menentukan hubungan batas atas dan bawah dengan sumbu yang akan diintegralkan dan salah dalam mengintegralkan fungsi dengan teknik substitusi. Kesalahan tersebut dapat terjadi karena ketidaktahuan dalam rumus dasar integral dan kurang memahami konsep dasar dari materi integral.

Dengan menyelesaikan soal menggunakan Matlab, kita dapat lebih cepat, mudah dan efisien dalam menyelesaikan soal matematika dibandingkan dengan penyelesaian secara manual. Karena tingkat kesalahan penulisan dan perhitungan dalam penyelesaian secara manual lebih mudah terjadi, sehingga tak jarang harus mengerjakan ulang dari awal hingga mendapatkan hasil yang benar-benar akurat.

Dalam penyelesaian soal matematika lainnya disarankan untuk menggunakan software yang dapat membantu, salah satunya adalah Matlab. Hasil dapat diperoleh dengan lebih cepat dan tersedia beberapa fitur lainnya pada Matlab, seperti grafik yang dapat lebih memudahkan peserta didik dalam memahami materi yang diberikan. 


\section{DAFTAR PUSTAKA}

Apriandi, D., \& Krisdiana, I. (2016). Analisis Kesulitan Mahasiswa dalam Memahami Materi Integral Lipat Dua Pada Koordinat Polar Mata Kuliah Kalkulus Lanjut. Jurnal Pendidikan Matematika, 123-134.

Cahyono, B. (2013). Penggunaan Software Matrix Laboratory (MATLAB) Dalam pembelajaran Aljabar Linear. Jurnal Phenomenon, 45-62.

Mauludya, N., \& Supriyo. (2021). Analisis Kesulitan Mahasiswa Dalam Pembuktian Rumus Luas Lingkaran Menggunakan Integral. 254-262.

Muchlis, E. E. (2017). Analisis Kesalahan Mahasiswa Pada Materi Integral Lipat di Prodi Pendidikan Matematika FKIP Universitas Bengkulu. Seminar Matematika dan Pendidikan Matematika UNY, 265-272.

Stewart, J. (2012). Multivariable Calculus. USA: Cengage Learning.

Suwanto, F. R., Tobondo, Y. V., \& Riskiningtyas, L. (2017). Kemampuan Abstraksi dalam Pemodelan Matematika. Seminar Matematika dan Pendidikan Matematika UNY, 301306.

Wahyuni, A., Kurniawan, P., S.B, W., \& Cahyono, A. N. (2019). Analisis Kesalahan Mahasiswa Dalam Menyelesaikan Soal Integral. Seminar Nasional Edusainstek FMIPA UNIMUS, 623-629. 